大学野球におけるストレートのリリース速度と回転速度の効力の検証 ${ }^{\dagger}$

林卓 史 ${ }^{*} * *$ 佐 野 毅 彦***

\title{
Verification of the Effects of the Release and Rotational Velocity of Four-seam Fastballs in College Baseball ${ }^{\dagger}$
}

\author{
Takafumi HAYASHI ${ }^{*} * *$ and Takehiko SANO***
}

\begin{abstract}
Purpose: To verify, quantitatively, how difficult the effects of release velocity [RLV] and the rotational velocity [RTV] of four-seam fastballs are for batters to hit and the effect of the RTV of fastballs on the type of shots in college baseball. Methods: Eight hundred forty fastballs thrown by University A's 11 pitchers in the 2017 league games were analyzed. The RLV was measured by a device installed in the stadium. The RTV were estimated by the RLV with the regression model, which was calculated from the data measured by the tracking system during the training session. To assess the difficulty to hit, a logistic regression analysis was used. To examine the type of shots, a chi-square analysis was used. Results: The RLV was significantly associated with swing and miss (odds ratio $[\mathrm{OR}]=1.07,95 \%$ confidence interval $[\mathrm{CI}]$ : 1.01-1.13), after adjusting for the number of strikes, meeting the minimum plate appearance requirement, and batting average. Compared with the moderate RTV fastballs (exceeding 1,928.7 rpm and 2,304.7 rpm or less; the reference group), the high RTV fastballs

(above 2,304.7 rpm) showed a significantly higher OR (1.90, 95\%CI: 1.17-3.10) of swing and miss. The OR of shots into the fair zone $(0.63,95 \%$ CI: $0.42-0.95)$ and of making a base hit $(0.49$, 95\% CI: $0.25-0.97)$ were significantly lower among the high RTV fastballs. A significant interaction was found between the estimated RTV and the type of shot $\left(\mathrm{x}^{2}=8.47, \mathrm{df}=2\right.$, $\mathrm{p}=.014)$. Conclusion: The higher the RLV of four-seam fastballs the more likely the result of a swing and miss. The high RTV fastballs result more likely in a swing and miss, less in shots into the fair zone and less in making a base hit, than the moderate RTV fastballs. The low RTV fastballs more likely result in grounders.
\end{abstract}

Key words : Pitching, Release Velocity, Rotational Velocity, Tracking System, College Baseball
1. 背
景
ス速度（投手の手元から離れる時点での直進速
度）が $150 \mathrm{~km} / \mathrm{h}$ に迫るストレートから $100 \mathrm{~km} / \mathrm{h}$
大学野球では, 投手が投じるボールはリリー
程度のチェンジアップのような变化球まで多彩

\footnotetext{
†原稿受付 2018年12月13日＼cjkstart原稿受諾２019年 2 月14日

*慶應義塾大学大学院政策・メディア研究科＝252-0882 神奈川県藤沢市遠藤5322

**朝日大学経営学部 厂501-0296 岐阜県瑞穂市穂積 1851

***慶應義塾大学大学院健康マネジメント研究科 †252-0883 神奈川県藤沢市遠藤4411

* Graduate School of Media and Governance, Keio University, 5322, Endo, Fujisawa, Kanagawa, Japan (252-0882)

** Faculty of Business Administration, Asahi University, 1851, Hozumi, Mizuho, Gifu, Japan (501-0296)

*** Graduate School of Health Management, Keio University, 4411, Endo, Fujisawa, Kanagawa, Japan (252-0883)
} 
である．たとえば，全日本大学野球連盟に加盟 するX連盟では, 2015年春季から2017年秋季ま での 6 シーズンに投手が投じた球種は 13 種類で あった（全222試合64,680球のうち球種を識別 できた 64,292 球が対象). 構成比上位 3 球種は ストレート $(59.0 \%)$, スライダー $(18.2 \%)$, カー ブ $(5.9 \%)$ であった（X連盟に加盟する A大学 野球部の記録担当の学生が作成したスコアブッ クに基づく集計結果). 構成比第 1 位のストレー 卜は全体の 6 割を占め, また, 第 2 位のスライ ダーの 3 倍以上の球数が投じられたことがわ かる. 投球の基本はストレートであるといわれ るが, これはストレートの重要性が示唆される データといえる。

ストレートはリリース速度が大きいほど打ち にくいと考えられている。投手板から本畦ま での距離は $18.44 \mathrm{~m}$ であるが，投手は軸足を投 手板に触れて置いた状態で他の足（踏み込み 足）を本罜方向へ踏み出して投げるため, 投手 のリリースポイント（ボールが投手の手元から 離れる位置) からバッターのコンタクトポイ ント（ボールにバットが当たる位置, 空振の 場合はボールとバットがすれ違う位置) までの 距離は $17 \mathrm{~m}$ 程度と想定される.コンタクトポイ ント到達時点でのボールの速度はリリース速 度から $5 \%$ 程度減少することが報告されている が1), この減少率を加味しても, リリース速度 $130 \mathrm{~km} / \mathrm{h}$ のスレートがリリースポイントか らコンタクトポイントまでに到達する時間は 0.5秒に満たない. 打撃のように, スイングする・ しないを選択する運動は $\mathrm{Go} / \mathrm{Nog} 0$ 課題と呼ば れるが, 熟練した打者の $\mathrm{Go} / \mathrm{Nog} 0$ 課題反応時 間は $0.2 \sim 0.3$ 秒と報告されており ${ }^{2)}$, スイング には 0.2 秒程度要することから ${ }^{3)}$, リリース速 度が大きければボールの見極めに充てられる時 間がより限定され, 安打を放つ難易度は必然的 に高まることになる。

リリース速度の大きさのほかに，伸びのある ストレートも打ちにくいと考えられる。伸びと は打者の主観的な評価であるが，バットスイン グの軌道がボール下側となるようなボールを指
すと考えられる.投手が投げるボールの軌道は, リリース速度, 回転速度, 投射角度, 回転軸 の方向, 空気密度の違いによって定まるとされ るが4), バックスピン（進行方向に対する逆回 転で, 回転軸の方向は進行方向と重力方向と直 交し一罢と三罢を結ぶ方向と平行）はボールに 揚力を生じさせ，バックスピンの回転速度が大 きいほどボールに作用する揚力が大きくなるこ と ${ }^{5)}$-7), ボールの回転軸が水平でボールの進 行方向と直交する場合に揚力は最大となり, 角 度が小さくなると揚力が弱まること帛 が報告 されている，ストレートの回転軸は $30^{\circ}$ 程度傾 いて扔り，軌道は進行方向に対して投球腕方向 （右投げの場合は 3 畦方向）へ傾くことが報告

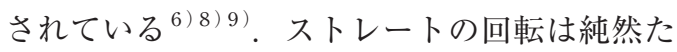
るバックスピンではないが, 他の変化球と比較 して相対的にバックスピンの傾向が強い ${ }^{9)}$ ため に揚力の影響は比較的強く，ストレートの軌道 の到達点は, 回転速度が大きい場合には上方, 小さい場合には下方となる。したがって，見慣 れた回転速度よりも回転速度が大きいストレー トの場合, 想定する軌道よりも到達点が上方と なるため, 打者はボールが浮き上がるような錯

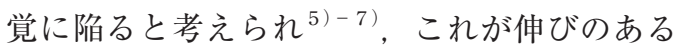
ストレートを意味し，ボール通過点より下側の 空振，あるいはボールの下側を打つことによる フライが多くなることが想定される．見慣れた 回転速度よりも回転速度が小さいストレートの 場合には, 到達点が想定より下方となるため, 打者がボールの上側を打つ傾向があることが報 告されており ${ }^{7}$, 打球はゴロが多くなることが 想定される.

先行研究から, 打ちにくいストレートの条件 は，リリース速度が大きく，標準的な（見慣れ た）回転速度からの乘離が大きい回転速度であ ることが想定される。また，回転速度が大きい と打球種類がフライとなり，小さいとゴロとな る傾向が想定される。これらは諸条件が統制さ れた実験に基づく結果から導き出された仮説で あり，実践との整合の度合いは明らかになって いないが, 第一著者（高校, 大学, 社会人で投 
手として全国大会出場経験があり，15年の投手 指導経験を有する）の経験に基づく実践知とは 符号する.

\section{2. 目的}

本研究では, 大学生投手が投げるストレート について, リリース速度と回転速度が打ちにく さに与える影響と, 回転速度が打球の種類に与 える影響を定量的に検証することを目的とす る. 本研究で得られた知見により, リリース速 度と回転速度という客観的な指標に基づいた ピッチング指導が可能となり，また，大学生投 手の技術向上やタレント発掘に寄与することが 期待される。

\section{3. 方法}

\section{1 対象}

全日本大学野球連盟に加盟する A大学野球部 に所属する投手のうち2017年リーグ戦 27 試合 (春季リーグ戦14試合、秋季リーグ戦13試合) に登板機会を得た 12 人（春季リーグ戦 9 人，秋 季リーグ戦 9 人）が投じたストレートを対象と した. なお, 投球 1 球ごとの結果は, 空振, ファ ウル (邪飛含む), 凡打 (失策出畋, 野手選択, 犠飛含む), 安打, 犠打, 見送, 死球のいずれ かであるが, 犠打, 見送, 死球では打者がバッ トをスイングしていない, すなわち打つ意思が ないと判断し, 分析対象から除外することとし た.

なお， A大学はX連盟に加盟しており， X連 盟からは多くのプロ野球選手やオリンピック日 本代表選手が輩出されており，さらに，同連盟 の春季リーグ戦優勝校は全日本大学野球選手権 大会で優勝25回, 準優勝 8 回, 秋季リーグ戦優 勝校は明治神宮野球大会で優勝 13 回, 準優勝 15 回という戦績を残していることから（2017年度 末時点), $\mathrm{X}$ 連盟の競技水準は大学最高レベル に相当するといえる.

\section{2 リリース速度と回転速度}

リリース速度は競技場に設置された計測器に
よる計測值とした、リーグ戦の試合はすべて同 一競技場で開催され，当該競技場内の大型映像 装置に整数值として表示されたリリース速度を 記録した。回転速度は計測值が表示されないた め, 練習時に計測したリリース速度と回転速 度に基づきリリース速度による回転速度の推 定式を算出し，この推定式を用いて競技場で表 示されたリリース速度から推定回転速度を求め た。練習時のリリース速度と回転速度はトラッ キングシステムRapsodo Baseball (Rapsodo, Indianapolis, USA）によって計測した。計測 期間はリーグ戦開催期間と同一とした。なお, リリース速度と回転速度との間の正の強い相関 関係が報告されていることから ${ }^{10)}$ ，リリース速 度と推定回転速度との間の関係をPearsonの積 率相関係数 $\mathrm{r}$ により確認することとした. また, リリース速度と推定回転式それぞれについて平 均值と標準偏差を求め, 平均值から標準偏差が 1 だけ離れた值で分割し, 低群(「平均值一標 準偏差」以下), 中群 (「平均值 - 標準偏差」超 $\lceil$ 平 均值 +標準偏差」以下), 高群 (「平均值 +標準 偏差」超）の 3 群からなる順序尺度へ変換した のち, リリース速度 3 群と推定回転速度 3 群に よるクロス集計を行い, リリース速度と推定回 転速度の分布状況を確認することとした。

\section{3 リリース速度と回転速度が打ちにくさ に与える影響の検証}

野球では投球結果に対する偶然の影響は過小 評価できない。バットの芯で捉えられた会心の 当たりが野手の正面を突けば記録上は凡打とな り，バットの芯を外れたゴロ（いわゆるボテボ テのゴロ）が野手の間隙を抜ければ記録上は安 打となる。リリース速度や回転速度といった球 質が投球結果に与える影響を検証するにあた り, 球質以外の諸要因の統制は難しい課題であ る. そこで本研究では, 目的変数に用いるアウ トカムを段階的に変え, リリース速度と推定回 転速度を説明变数とするロジスティック回帰分 析を行うこととした．第一段階のアウトカムは 空振か否かとした。ボールにバットを当てられ 
なければ, 安打となる偶然の余地はないからで ある. 第二段階のアウトカムは, ボールをフェ アゾーンに打ち返されたか否かとした。 バッ トコントロールや風などの影響は否めないが, フェアゾーンに打ち返されなければ, 安打とな る偶然の余地はないからである。第三段階は, バットコントロールや風, 守備位置, グラウン ドコンディションなどの影響は否めないが, 安 打か否かとした. 説明変数となるリリース速度 については, 大きければ打ちにくさが増すと想 定されるため, 比率尺度のまま用いることとし た. 回転速度については, 標準的な回転速度か らの偏差が大きい（すなわち，見慣れない回転 速度である）と打ちにくさが増すと想定される ため, 順序尺度化した推定回転速度を用いるこ ととし, 参照カテゴリーは中群とした.リリー 又速度と順序尺度化した推定回転速度との多重 共線性の有無はSpearmanの順位相関係数 $\rho$ で 確認することとした，ストライクカウントや打 者の技術水準の影響は無視できないため, 調整 変数としてストライクカウント数, 規定打席数 ( $\mathrm{X}$ 連盟規定: 試合数 $\times 3.1)$ 到達の有無, 打率 (安 打数を打数で除した値) を用いることとした. 有意水準は $5 \%$ とし, 解析にはSPSS ver.25 （IBM）を用いた。また，ロジスティック回帰 分析と併せて, 順序尺度化したリリース速度 3 群と推定回転速度 3 群の組み合わせ別に, 空振, フェアゾーン, 安打それぞれの比率を確認する こととした.

\section{4 回転速度が打球の種類に与える影響を \\ 検証}

先行研究より, 打球の種類は, 回転速度が小 さいほどゴロとなる傾向が強く, 大きいほどフ ライとなる傾向が強くなることが想定される. 打球種類は一般的にゴロ, フライ, ライナーで 識別されるが，打たれたボールがフイールド上 でバウンドあるいは転がりながら進行する状態 をゴロと判断することは容易であるが, 打った ボールがフィールド上に接地することなく捕球 されるもしくは場外に達する状態をフライとラ
イナーに分けて客観的に識別するのは容易では ない. そこで, 打球種類をゴロか否かとし, 名 義尺度化した推定回転速度（低中高の 3 群）と 打球種類（ゴロ・非ゴロ）との関連の有無を $\chi^{2}$ 検定にて検証することにより, 回転速度が 打球種類に与える影響を確認することとした. 有意水準は $5 \%$ とし, 解析にはSPSS ver.25 （IBM）を用いた。

\section{5 倫理的配慮}

本研究で用いたデー夕は, 研究の目的, プラ イバシーの保護, 研究協力の任意性, 研究デー 夕の取り扱い, 研究結果の公表方法に関する説 明を行い, 同意を得たうえで A大学野球部から 提供された。個人名や大学名などの固有名詞は すべて匿名化した，本研究は慶應義塾大学大学 院政策・メディア研究科倫理審査委員会の許 可を得て実施された（受理番号：141, 承認日： 2017年 3 月 21 日).

\section{4. 結果}

\section{1 対象}

2017 年リーグ戦に登板機会を得た投手 12 人の うち練習時にリリース速度と回転速度を計測で きなかった 1 人を除外し，11人を分析対象と した.この11人がリーグ戦で投じたストレー 卜は合計2,136球であった，犠打 (35球)，見送 (1,183球), 死球 (11球) を除外した907球のう ち，リリース速度が競技場内に表示されたのは 840球であった（有効率93\%)。有効球の内訳は 空振127球 (15\%), ファウル375球 (45\%), 凡 打 222 球 (26\%), 安打116球(14\%)であった。 バッ トに当てられたボールは713球で, その内訳（打 球種類）はゴロ 230 球 (32\%), 非ゴロ 483 球 (68\%) であった。

\section{2 リリース速度と回転速度}

対象投手 11 人それぞれの練習時のリリース速 度と回転速度の分布状況, リリース速度による 回転速度の推定式は図 1 のとおりであった。

リーグ戦で投じたられたストレートのうち分 


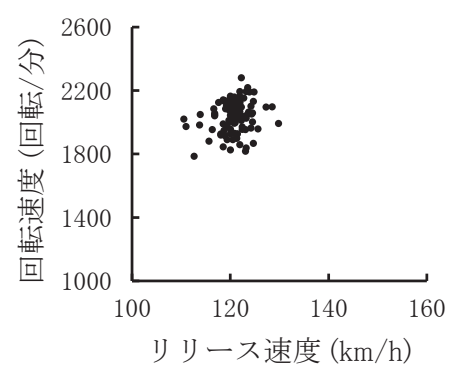

$\mathrm{y}=6.4 \mathrm{x}+1266.8, \mathrm{R}^{2}=.04$

投手 1

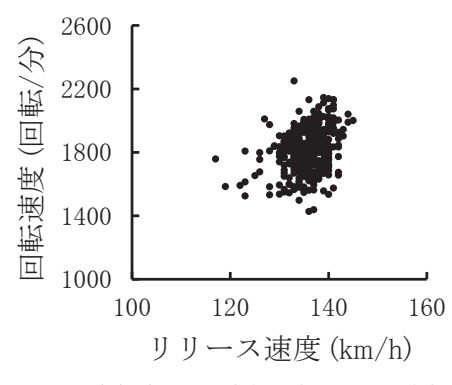

$\mathrm{y}=11.1 \mathrm{x}+305.3, \mathrm{R}^{2}=.09$

投手 4

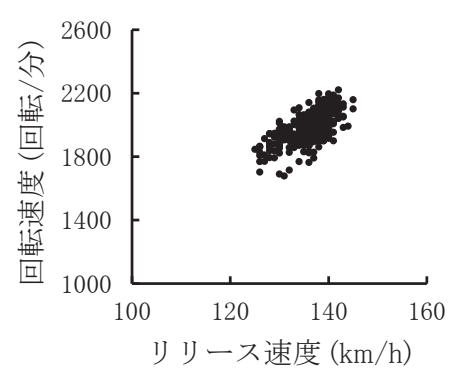

$y=15.3 x-93.2, R^{2}=.41$

投手 7

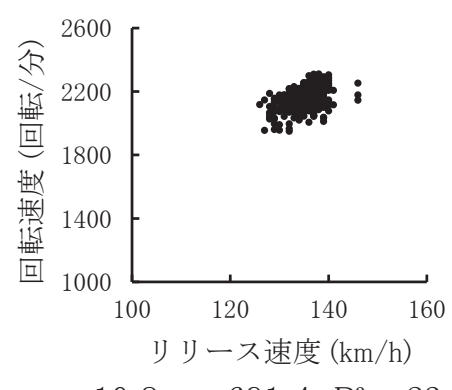

$\mathrm{y}=10.8 \mathrm{x}+691.4, \mathrm{R}^{2}=.23$

投手 10

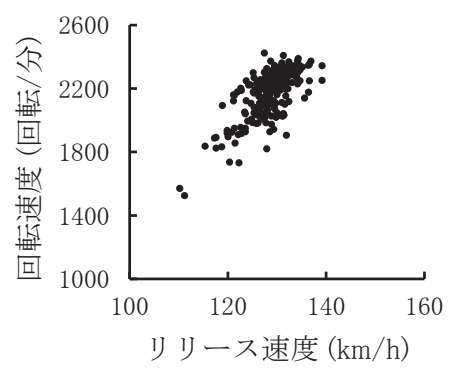

$\mathrm{y}=24.7 \mathrm{x}-1003.4, \mathrm{R}^{2}=.52$

投手 2

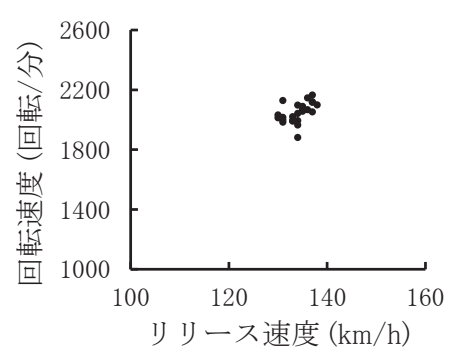

$$
\mathrm{y}=14.6 \mathrm{x}+86.6, \mathrm{R}^{2}=.28
$$

投手 5

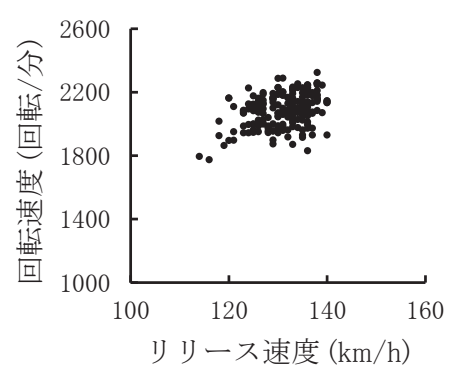

$$
y=7.8 x+1068.8, R^{2}=.15
$$

投手 8

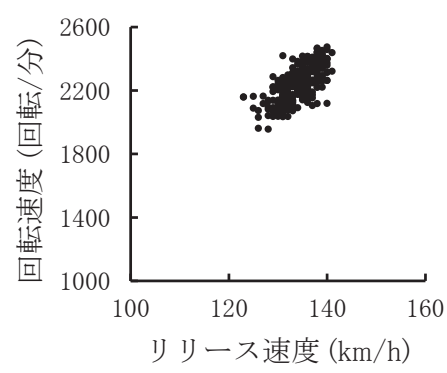

$y=21.5 x-631.2, R^{2}=.46$

投手 11

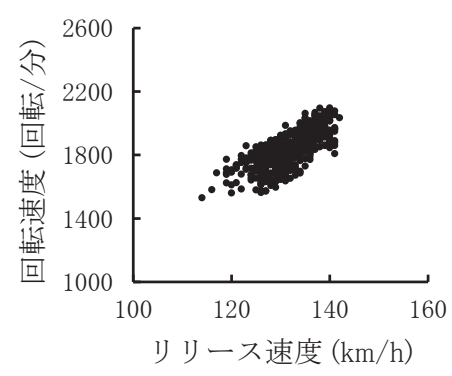

$y=16.4 x-327.0, R^{2}=.55$

投手 3

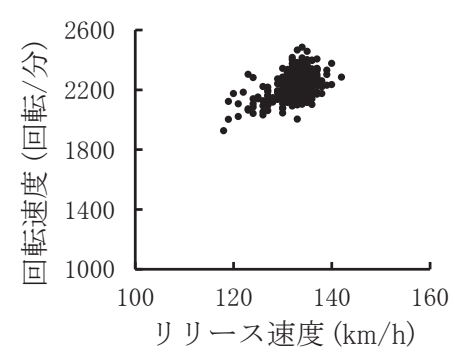

$\mathrm{y}=12.5 \mathrm{x}+577.5, \mathrm{R}^{2}=.28$

投手 6

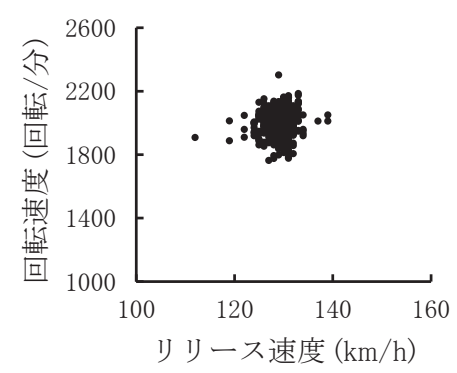

$y=4.2 x+1481.1, R^{2}=.02$

投手 9

図 1 練習時の投手別ストレートのリリース速度と回転速度の分布状況 
析対象840球のリリース速度の平均值（標準偏 差）は137.5(4.4) km/h, 最小值は $118 \mathrm{~km} / \mathrm{h}$, 最大值は $148 \mathrm{~km} / \mathrm{h}$ であった。練習時の計測結 果から算出したリリース速度による回転速度の 推定式を用いてリーグ戦での回転速度を求めた 結果, 平均值（標準偏差）は2,116.7（188.0）回 転/分, 最小值は 1,740 回転/分, 最大值は 2,544 回転/分であった.リリース速度と推定回転速 度との間には有意な正の弱い相関が認められた $(\mathrm{r}=.372, \mathrm{p}=.000) . リ リ ー ス$ 速度 $(\mathrm{km} / \mathrm{h})$ の「平均值 - 標準偏差」は133.1, 「平均值 + 標準偏差」は141.8であったことから, 低群は $133.1 \mathrm{~km} / \mathrm{h}$ 以下, 中群は $133.1 \mathrm{~km} / \mathrm{h}$ 超 $141.8 \mathrm{~km} / \mathrm{h}$ 以下, 高群は $141.8 \mathrm{~km} / \mathrm{h}$ 超となった。推定回転 速度 (回転/分)の「平均值 - 標準偏差」は1,928.7, 「平均值 +標準偏差」は2,311.4であったことか ら, 低群は1,928.7以下, 中群は1,928.7超2,304.7 以下, 高群は2,304.7超となった。順序尺度化し

表 1 リリース速度・推定回転速度別ストレート の分布 $(n=840)$

\begin{tabular}{|c|c|c|c|c|c|}
\hline & \multicolumn{4}{|c|}{ 回転速度 } \\
\hline & & 低群 & 中群 & 高群 & 計 \\
\hline \multirow{4}{*}{ 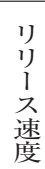 } & 低群 & $1.2 \%$ & $14.3 \%$ & - & $15.5 \%$ \\
\hline & 中群 & $14.2 \%$ & $43.0 \%$ & $11.0 \%$ & $68.1 \%$ \\
\hline & 高群 & $0.6 \%$ & $6.4 \%$ & $9.4 \%$ & $16.4 \%$ \\
\hline & 計 & $16.0 \%$ & $63.7 \%$ & $20.4 \%$ & $100.0 \%$ \\
\hline
\end{tabular}

たリリース速度 3 群と推定回転速度 3 群のクロ ス集計による分析対象ストレートの分布状況は

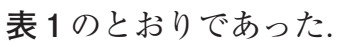

\section{3 リリース速度と回転速度が打ちにくさ に与える影響の検証}

リリース速度と順位尺度化した推定回転速度 との間に有意な正の弱い相関関係が認められた が $(\rho=.374, \mathrm{p}=.000)$, 多重共線性の影響 はないと判断した．投球結果を示す 3 つアウ トカム, 空振 (空振か否か), フェアゾーン（打 球をフェアゾーンに打ち返されたか否か), 安 打 (安打か否か) を目的变数, リリース速度と 順序尺度化した推定回転速度を説明变数, ス卜 ライクカウント数, 規定打席到達の有無, 打率 を調整変数とするロジスティック回帰分析を 行った結果を表 2 に示す.

空振を目的変数 $(1=$ 空振, $0=$ 非空振 $)$ と する解析の結果, 空振とリリース速度との間に 有意な関連が認められ，オッズ比（95\%信頼区 間）は1.07（1.01-1.13）であった。推定回転 速度については, 中群と低群との差は認められ なかったが, 中群と比べて高群のオッズ比 $(95 \%$ 信頼区間）は1.90（1.17-3.10）と有意に高い 值を示した.フェアゾーンを目的変数 $(1=$ フェ アゾーン， 0 =非フェアゾーン）とする解析の 結果，フェアゾーンとリリース速度との間に有

表2 リリース速度・推定回転速度と投球結果との関連

\begin{tabular}{|c|c|c|c|c|c|c|c|c|c|}
\hline & \multicolumn{3}{|c|}{ 空振 } & \multicolumn{3}{|c|}{ 非フェアゾーン } & \multicolumn{3}{|c|}{ 非安打 } \\
\hline & OR & $95 \% \mathrm{CI}$ & $\mathrm{p}$ & OR & $95 \% \mathrm{CI}$ & $\mathrm{p}$ & OR & $95 \% \mathrm{CI}$ & $\mathrm{p}$ \\
\hline リリース速度 & 1.07 & $1.01-1.13$ & .024 & 0.98 & $0.95-1.02$ & .337 & 0.97 & $0.92-1.02$ & .218 \\
\hline 推定回転速度 & & & & & & & & & \\
\hline 低群 & 0.71 & $0.38-1.34$ & .294 & 0.96 & $0.65-1.42$ & .842 & 0.92 & $0.54-1.59$ & .771 \\
\hline 中群 & 1.00 & & & 1.00 & & & 1.00 & & \\
\hline 高群 & 1.90 & $1.17-3.10$ & .010 & 0.63 & $0.42-0.95$ & .029 & 0.49 & $0.25-0.97$ & .042 \\
\hline
\end{tabular}

調整変数: ストライクカウント数, 規定打席到達の有無, 打率

OR：オッズ比, 95\%CI：95\%信頼区間

空振 : 空振か否か $(1=$ 空振, $0=$ 非空振 $)$

フェアゾーン：打球をフェアゾーンに打ち返されたか否か（1＝フェアゾーン， 0 = 非フェアゾーン $)$

安打 : 安打か否か $(1=$ 安打, 0 = 非安打 $)$ 
意な関連は認められず, 推定回転速度について は, 中群と低群との差は認められなかったが, 中群と比べて高群のオッズ比（95\%信頼区間） は0.63（0.42-0.95）と有意に低い值を示した. 安打を目的変数 ( 1 =安打, $0=$ 非安打 $)$ とす る解析の結果, 非安打とリリース速度との間に は有意な関連は認められず, 推定回転速度につ いては, 中群と低群との差は認められなかった が, 中群と比べて高群のオッズ比（95\%信頼区 間）は0.49（0.25-0.97）と有意に低い值を示 した。

順序尺度化されたリリース速度 3 群と推定回 転速度 3 群の組み合わせ別の空振, フェアゾー ン, 安打それぞれの比率は表 3〜表5のとおり であった，空振の比率は平均 $15 \%$ で, リリース 速度高群 ・ 回転速度高群 (30\%) とリリース速 度中群・回転速度高群 (24\%) が高い傾向にあ り, その他の群は平均值以下であった（表 3 ).

フェアゾーンの比率は平均 $40 \%$ で, リリース 速度高群・回転速度高群（25\%）とリリース速 度中群・回転速度高群 (34\%) が低い傾向にあ り, その他の群は平均值以上であった（表 4).

安打の比率は平均 $14 \%$ で, リリース速度高群. 回転速度高群 (4\%) とリリース速度高群・回 転速度低群（０％）が低い傾向にあり, リリー 又速度高群・回転速度中群（11\%）とリリース 速度低群 ・ 回転速度低群（10\%）が平均值をや や下回る低い傾向にあり, その他の群は平均值 を上回った（表 5).

\section{4 回転速度が打球の種類に与える影響の \\ 検証}

推定回転速度と打球種類との関連の有無を $\chi^{2}$
乗検定にて検証した結果，有意な関連が認めら れた $\left(\chi^{2}=8.48, \mathrm{df}=2, \mathrm{p}=.014\right.$; 表 6$)$. 推 定回転速度低群ではゴロの比率 $(40 \%)$ が高い 傾向にあり，高群ではゴロの比率 $(23 \%)$ が低 い傾向にあることが示唆された.

\section{表 3 リリース速度・推定回転速度別空振率}

\begin{tabular}{|c|c|c|c|c|c|}
\hline & \multicolumn{4}{|c|}{ 回転速度 } \\
\hline & & 低群 & 中群 & 高群 & 計 \\
\hline \multirow{4}{*}{ 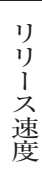 } & 低群 & $0 \%$ & $9 \%$ & - & $9 \%$ \\
\hline & 中群 & $11 \%$ & $14 \%$ & $24 \%$ & $15 \%$ \\
\hline & 高群 & $0 \%$ & $15 \%$ & $30 \%$ & $23 \%$ \\
\hline & 計 & $10 \%$ & $13 \%$ & $27 \%$ & $15 \%$ \\
\hline
\end{tabular}

注）ストレート840球のうち空振は 127 球

表 4 リリース速度・推定回転速度別フェアゾー ン率

\begin{tabular}{|c|c|ccc|c|}
\hline \multicolumn{2}{|c|}{} & \multicolumn{4}{|c|}{ 回転速度 } \\
\cline { 2 - 6 } & 低群 & 中群 & 高群 & 計 \\
\hline リ & 低群 & $40 \%$ & $48 \%$ & - & $47 \%$ \\
等 & 中群 & $43 \%$ & $42 \%$ & $34 \%$ & $41 \%$ \\
杀 & 高群 & $40 \%$ & $43 \%$ & $25 \%$ & $32 \%$ \\
\cline { 2 - 5 } 度 & 計 & $43 \%$ & $43 \%$ & $30 \%$ & $40 \%$ \\
\hline
\end{tabular}

注）ストレート840球のうちフェアゾーンへ打ち返 されたのは 338 球

表 5 リリース速度・推定回転速度別安打率

\begin{tabular}{|c|c|c|c|c|c|}
\hline & \multicolumn{4}{|c|}{ 回転速度 } \\
\hline & & 低群 & 中群 & 高群 & 計 \\
\hline \multirow{4}{*}{$\begin{array}{l}\text { y } \\
\text { y } \\
\text { 1 } \\
\text { 速 } \\
\text { 度 }\end{array}$} & 低群 & $10 \%$ & $18 \%$ & - & $18 \%$ \\
\hline & 中群 & $16 \%$ & $16 \%$ & $10 \%$ & $15 \%$ \\
\hline & 高群 & $0 \%$ & $11 \%$ & $4 \%$ & $7 \%$ \\
\hline & 計 & $15 \%$ & $16 \%$ & $7 \%$ & $14 \%$ \\
\hline
\end{tabular}

注）ストレート840球のうち安打は116球

表 6 推定回転速度別打球種類構成比の比較

\begin{tabular}{ccccccc}
\hline 推定回転速度 & $\mathrm{n}$ & ゴロ & 非ゴロ & $\chi^{2}$ & $\mathrm{df}$ & $\mathrm{p}$ \\
\hline 低群 & 121 & $40 \%$ & $60 \%$ & 8.48 & 2 & .014 \\
中群 & 467 & $33 \%$ & $67 \%$ & & & \\
高群 & 125 & $23 \%$ & $77 \%$ & & & \\
計 & 713 & $32 \%$ & $68 \%$ & & & \\
\hline
\end{tabular}

ASR：調整済み標準化残差, $\mathrm{df}$ : 自由度 


\section{5. 考察}

\section{1 ストレートのリリース速度と回転速度} が打ちにくさに与える影響

リリース速度が大きいストレートは打ちにく く, また, 回転速度が小さいもしくは大きいス トレートも打ちにくいことが想定されたことか ら, 大学生投手を対象として, リリース速度と 回転速度がストレートの打ちにくさに与える影 響を定量的に検証するため, 投球結果を示す 3 つの段階別アウトカムを目的変数, リリース 速度と順序尺度化した推定回転速度を説明変 数, ストライクカウント数, 規定打席到達の有 無, 打率を調整変数とするロジスティック回帰 分析を行った．空振を目的変数とした場合（1 = 空振, 0 = 非空振), リリース速度のオッズ 比（1.07）は有意に高い值を示し, 推定回転速 度中群と比較して高群のオッズ比（1.90）は有 意に高い值を示した.フェアゾーン（打球をフェ アゾーンに打ち返されたか否か) を目的変数と した場合（１＝フェアゾーン， 0 = 非フェア ゾーン), 推定回転速度中群と比較して高群の オッズ比（0.63）は有意に低い值を示した。安 打を目的変数とした場合 ( 1 =安打, $0=$ 非安 打), 推定回転速度中群と比較して高群のオッ ズ比（0.49）は有意に低い值を示した. 以上か ら,リリース速度が大きくなるほど空振の確率 が高まることが示唆された。つまり,リリース 速度の増加は, バットにボールを当てさせない 確率を高めることにはつながるが, バットに当 てさせてしまうとその後の結果には影響を及ぼ さないことが推察される. また, 推定回転速度 高群は2,304.7回転/分超であることから，およ そ2,300回転/分を超える回転速度があれば空振 の確率が高まり, フェアゾーンに打ち返される 確率は低くなり, 安打を打たれる確率も低くな ることが示唆された。

\section{2 ストレートの回転速度が打球の種類に}

\section{与える影響}

回転速度が大きいと打球種類がフライとな
り，小さいとゴロとなる傾向が想定されること から, 順序尺度化した推定回転速度と打球種 類との関連の有無を $\chi^{2}$ 検定にて検証した結果, 有意な関連が認められ，推定回転速度低群では ゴロの比率が高い傾向にあり, 高群ではゴロの 比率が低い傾向にあることが示唆された．この 結果は先行研究と符合するものであり, 実験の 場で得られた結果は実践の場にも適用されるこ とが証明されたとみなすことができる。

\section{3 ストレートのリリース速度と回転速度 に基づく指導指針}

以上の結果を踏まえると，ストレートのリ リース速度と回転速度に基づき, 以下のような 投手の指導指針が導き出せると考えられる。リ リース速度と回転速度が大きいストレートを投 げる投手に対しては二段階の指導を行い，第一 段階では強く腕を振ってストレートを投げる ことを求め, 第二段階では高めのコースへスト レートを積極的に投げることを求めることが妥 当であると考える. 投球動作は, 軸足から踏み 达み足への重心移動を伴う並進運動と, 股関節 を中心とした骨盤の回旋, やや遅れての体幹の ひねり，体幹の回旋に伴う上腕（肩関節）の回 旋, 続く前腕（肘）の回旋, さらに肘伸展へ のブレーキによる手 (手首) の加速という回 旋運動から成る運動連鎖（kinetic chain）であ る ${ }^{11)-13)}$.リリース速度と回転速度が大きいと いうことは, 一連の運動連鎖から生み出される エネルギーが効率的にボールに伝達されている と考えられる.リリース速度と回転速度が大き いストレートを投げるためには，強く腕を振る こと，すなわち主観的努力度を高めて投げるこ とが求められるが, 主観的努力度の増加はリ リース速度の増加とコントロールの精度低下に つながることが報告されている ${ }^{14)}$. 低めにコン トロールされたボールを投げることがピッチン グの定石といわれるが, 低めへのコントロール の意識が強くなりすぎると，ボールへ伝えられ るエネルギーの減衰を招く可能性は否定できな いと考えられる。リリース速度と回転速度が大 
きいストレートは空振の確率が高く, バットに 当てられても打球がフェアゾーンに到達する確 率は低く, 安打となる確率も低いことが期待さ れる，そのゆえ，コントロールの精度を多少犠 牲にしても, 強く腕を振ってストレートを投げ ることを指導する必要があると考えられる。回 転速度が大きいストレートについては, バッ トスイングの軌道はボール下側となる傾向が 強いことからバットに当てられても打球はフラ イアウトになることが期待できるため, 腕を強 く振って投げても狙ったコースへ投げるコント ロールの精度が身についた段階では, 高めの コースヘストレートを積極的に投げることを指 導することが妥当であると考えられる。

リリース速度は大きいが回転速度は小さいス トレートを投げる投手に対しては, 低めのコー スへ安定的に投げるコントロールの精度とリ リース速度のさらなる増加, 垂直方向への変化 量が大きい変化球の習得を求めることが妥当で あると考える. 回転速度が小さいストレートに 対するバットスイングの軌道はボール上側とな る傾向が高いため打球はゴロとなる確率が高く なるが，ゴロを打たせる確率をより高めるため に，投げ込むコースを低めに限定することが必 要となる。より大きなりリース速度を求めるの は，打者がボールを見極める時間をより制限し て打ちにくさを増すためである. また, ツーシー ムやフォークボールといった水平方向よりも垂 直方向への変化量が大きい（いわゆる, 落ちる) 変化球と組み合わせることによって, このスト レートの特徴をさらに活かすことができると考 えられる。

リリース速度と回転速度が小さいストレート を投げる投手に対しては, 精度の高いコント ロールと変化球主体の配球を求めることが妥当 であると考える.リリース速度が小さいボール は打者には見極められやすいので，ストレート で打者を抑えることは難しいと考えられ，必然 的に配球は変化球主体にならざるを得ないこと になる. 回転速度が小さいストレートはゴロと なる確率が高いという特徴を活かすために, 投
げ込むコースを低めに限定することは必須とな る。リリース速度も回転速度も小さいストレー 卜を投げる投手の起用は消極的にならざるを得 ないが, 変則的な投球動作を習得することに よって打ちにくさを高めることの可能性は否定 できないと考えられる。

リリース速度, 回転速度とも中程度のスト レートは打者には見慣れた特徵のないボールと いえる。このようなストレートを投げる投手に 対しては，ストレート以外で何らかの特徵を引 き出すような指導が必要になると考えられる。

リリース速度が小さく回転速度が大きいス卜 レートは, 本研究ではリリース速度が $133.1 \mathrm{~km} / \mathrm{h}$ 以下, 回転速度が2,304.7回転/分超のストレー 卜を意味するが，A大学所属投手が投じたボー ルには観測されなかった．並進運動と回旋運動 から成る投球動作によって生み出されたエネル ギーがボールの直進運動と回転運動に変換され ると考えるならば, 直進運動への変換効率は低 く回転運動への変換効率は高いことを意味する と捉えられる。このようなストレートを否定す る根拠はないが, リリース速度と回転速度との 間には正の相関関係が認められることや ${ }^{10)}$ ，第 一著者の指導経験を踏まえると，このようなス トレートを投げる投手の存在の可能性は極めて 低いと考えられる，そのため，本研究では，指 導指針の検討対象からは除外することとした。

\section{4 研究の限界と今後の課題}

本研究にはいくつかの限界がある。第一の限 界は, 本研究で検証に用いた回転速度は推定值 であり，試合で投じられたストレートを直接測 定した結果ではない点である. 投げ損ないによ り回転速度が小さくなった場合など, 回転速度 の群分けが正しく行われない可能性は否定でき ない. 第二の限界として, 回転軸の方向が考慮 されていない点が挙げられる. 回転軸の方向に よって揚力の強さは変わるため ${ }^{6)}$, 回転速度の 評価方法に改善の余地が残ることは否定できな い. 第三の限界として, リリース速度と回転速 度以外の要因, 例えば, ボールのロケーション 
や配球，投球動作などが考慮されていない点が 挙げられる. 多くの打者は外角低めのストレー 卜は苦手にしており ${ }^{15)}$, 球種が多いと予測が難 しくなるため ${ }^{16}$ 打ちにくさが助長される。この ように,リリース速度と回転速度以外の諸要因 が投球結果に与える影響は否定できない。第四 の限界として，打者の技能を統制するために用 いた調整変数は規定打席到達の有無と打率だけ である点が挙げられる。プロ野球やアメリカの Major League Baseball と異なり, 日本の大学 野球では 1 シーズンの試合数は多くないため, 1 打席が打率に与える影響は小さくない。バッ トスイングの速さなど計測可能な変数の導入が 候補に挙げられるが, 適正な变数の見極めは容 易ではない，第五の限界として，A大学野球部 所属投手 11 人の 2017 年リーグ戦 27 試合の投球結 果を対象として検証されており, 結果の一般化 には注意が必要である点が挙げられる。

今後の課題として, 試合でのリリース速度と 回転速度（回転軸の方向含む）を計測すること が挙げられる。ボールのロケーションについて も, 測定方法や変数として取り扱い方法を含め て課題として挙げられる. また, 多様な投手を 対象として, サンプル数を増やすことも課題と して挙げられる。

\section{6. 結}

\section{論}

本研究では, A大学野球部所属投手 11 人の 2017年リーグ戦27試合を対象に, リリース速度 と回転速度がストレートの打ちにくさに与える 影響と, ストレートの回転速度が打球の種類に 与える影響を定量的に検証することを目的とし た。リリース速度はリーグ戦での計測值を用い た. 回転速度は, 練習時の計測值に基づく回帰 式を用いてリリース速度から推定值を算出した うえで, 平均值士標準偏差の点で 3 分割して順 序尺度化した。投球結果を目的変数, リリース 速度と順位尺度化した推定回転速度を説明変 数, アウトカウント数, 規定打席到達の有無, 打率を調整変数とするロジスティック回帰係数 を行った結果, リリース速度が大きくなるほど
空振の確率が高まり，回転速度が大きい（およ そ2,300回転/分超) と空振の確率が高まり, フェ アゾーンに打ち返される，あるいは安打を打た れる確率が低く抑えられることが示唆された。 また, 推定回転速度と打球種類との関連の有無 を $\chi^{2}$ 検定にて検証した結果, 有意な関連が認 められ, 推定回転速度が小さいとゴロの比率が 高くなる傾向にあり，大きいとゴロの比率が低 くなる傾向にあることが示唆された.

これらの結果を踏まえ，以下のリリース速度 と回転速度に基づく指導指針案が示された。す なわち, リリース速度と回転速度が大きい久 トレートを投げる投手に対してはまず強く腕 を振ってストレートを投げること，次に高め のコースヘストレートを積極的に投げることを 求める；リリース速度は大きいが回転速度は小 さいストレートを投げる投手に対しては低めの コースへ安定的に投げるコントロールの精度と リリース速度のさらなる増加, 落ちる変化球の 習得を求める；リリース速度と回転速度が小さ いストレートを投げる投手に対しては，精度の 高いコントロールと変化球主体の配球を求め る; リリース速度, 回転速度とも中程度のス卜 レートを投げる投手に対してはストレート以外 の特徵を求める.

\section{参 考 文 献}

1) Alaways, L. W., et al. ; Identification of release conditions and aerodynamic forces in pitched-baseball trajectories, Journal of Applied Biomechanics, Vol.17, No.1, pp.63-76, 2001.

2 ) Kida, N., et al. ; Intensive baseball practice improves the Go/Nogo reaction time, but not the simple reaction time. Cognitive Brain Research, Vol.22, No. 2, pp.257-264, 2005.

3 ) 那須大毅. 野球の投手-打者対戦からみたバッ ティングの時間構造. 日本神経回路学会誌, Vol.24, No.3, pp.132-137, 2017.

4) Kreighbaum, E. F. and Hunt, W. A. ; Relative factors influencing pitched baseballs, In : International Congress on Physical Activity Sci- 
ences, Quebec City, 11-16 July 1976, pp.227236, 1976.

5 ) Watts, R. G. and Ferrer, R. ; The lateral force on a spinning sphere : aerodynamics of a curveball, American Journal of Physics, Vol.55, pp.40-45, 1987.

6 ) Jinji, T. and Sakurai, S. ; Direction of spin axis and spin rate of the pitched baseball, Sports Biomechanics, Vol.5, No.2, pp.197-214, 2006.

7 ) Higuchi T., et al. ; The effect of fastball backspin rate on baseball hitting accuracy, Journal of Applied Biomechanics, Vol.29, No.3, pp.279284, 2013.

8 ) Nagami T., et al. ; Spin on fastballs thrown by elite baseball pitchers, Medicine \& Science in Sports \& Exercise, Vol.43, No.12, pp.23212327, 2011.

9 ）永見智行, 他; 野球投手が投じる様々な球 種の運動学的特徵, 体育学研究, Vo.61, No.2, pp.589-605, 2016.

10）神事努, 桜井伸二; 投球されたボールの球質は
どのような動作によって決定されるのか? バ イオメカニクス研究. Vol.12, No.4, pp.267-277, 2008 .

11）三原研一 ; バイオメカニクスと投球フォーム, 関節外科, Vol.27, No.8, pp.32-42, 2008.

12）内田智也, 他; 投球動作の Early cocking期 における軸足股関節の運動学・運動力学的特 徵, 日本臨床スポーツ医学会誌, Vol.25, No.1, pp.16-23, 2017.

13) Hirashima, M., et al. ; Kinetic chain of overarm throwing in terms of joint rotations revealed by induced acceleration analysis, Journal of Biomechanics, Vol.41, No.13, pp.28742883, 2008.

14）前田正登, 大岡昌平 ; 野球の投球における主観 的努力度がボールの初速度と正確さに及ぼす 影響. シンポジウム：スポーツ・アンド・ヒュー マン・ダイナミクス講演論文集2011, pp.45-50, 2011.

15）野村克也；野村ノート, 小学館, pp.45-46, 2009.

16）古田敦也；フルタの方程式, 朝日新聞出版, pp.97-99, 2009. 